\title{
Rainfall reduction impacts rhizosphere biogeochemistry in eucalypts grown in a deep Ferralsol in Brazil
}

\author{
Céline Pradier • Philippe Hinsinger • Jean-Paul Laclau • Jean-Pierre Bouillet • \\ Irae Amaral Guerrini • José Leonardo Moraes Gonçalves • Verónica Asensio • \\ Cassio H. Abreu-Junior • Christophe Jourdan (1)
}

Received: 10 June 2016 / Accepted: 8 November 2016/Published online: 6 December 2016

(C) Springer International Publishing Switzerland 2016

\begin{abstract}
Background and aims Comparing root functioning under contrasting rainfall regimes can help assessing the capacity of plant species to cope with more intense and frequent drought predicted under climate change context. While the awareness of the need to study the whole root system is growing, most of the studies of root functioning through rhizosphere analyses have been restricted to the topsoil. Our study aimed to assess whether the depth in the soil and the rainfall amount affect root functioning, and notably the fate of nutrients within the rhizosphere.
\end{abstract}

Editorial Responsibility: Elizabeth M. Baggs

Electronic supplementary material The online version of this article (doi:10.1007/s11104-016-3107-7) contains supplementary material, which is available to authorized users.

C. Pradier · J.-P. Laclau • J.-P. Bouillet $\cdot$ C. Jourdan $(\bowtie)$ CIRAD, UMR Eco\&Sols, 2 Place Viala, 34060 Montpellier, France

e-mail: christophe.jourdan@ cirad.fr

P. Hinsinger

INRA, UMR Eco\&Sols, 2 Place Viala, 34060 Montpellier, France

I. A. Guerrini

FCA, UNESP, CEP 18610-307 Botucatu, SP, Brazil

J. L. M. Gonçalves

LCF, ESALQ, CEP 13400-970 Piracicaba, SP, Brazil

V. Asensio - C. H. Abreu-Junior

CENA, ESALQ, CEP 13400-970 Piracicaba, SP, Brazil
Methods We compared $\mathrm{pH}$ and nutrient availability within the rhizosphere and bulk soil along a 4-m deep soil profile in a 5-year-old eucalypt (Eucalyptus grandis) plantation under undisturbed and reduced rainfall treatments.

Results The exchangeable $\mathrm{K}$ concentration and the $\mathrm{pH}$ of the bulk soil were not influenced by the reduced rainfall treatment. By contrast, the $\mathrm{H}_{3} \mathrm{O}^{+}$ concentration in the rhizosphere was significantly greater than that of the bulk soil, only in the reduced rainfall plot. The concentrations of exchangeable $\mathrm{K}$ in the rhizosphere were significantly larger than those of the bulk soil in both treatments but this difference was higher in the reduced rainfall plot, notably below the depth of $2 \mathrm{~m}$. Both exchangeable $\mathrm{K}$ and $\mathrm{H}_{3} \mathrm{O}^{+}$concentration significantly increased within the rhizosphere in the reduced rainfall treatment at soil depth down to $4 \mathrm{~m}$. Conclusions The amount of $\mathrm{K}$ brought to the roots by mass flow was estimated and could not explain the observed increase in exchangeable $\mathrm{K}$ concentration within the rhizosphere. A more likely explanation was root-induced weathering of K-bearing minerals, partly related to enhanced rhizosphere acidification. Our results demonstrate that root functioning can be considerably altered as a response to drought down to large depths.

Keywords Eucalyptus grandis · Fine root · Soil depth · $\mathrm{pH} \cdot$ Exchangeable potassium cation 


\section{Introduction}

The evaluation of ecosystem adaptation under changing environmental conditions has been recently a major focus, climate change being now recognized as a significant threat to sustainable development and crop production. In many parts of the world, climatic anomalies have occurred and will keep on intensifying in the coming future. Altered precipitation and temperature regimes as a result of climate change are expected to exacerbate the intensity and frequency of future droughts and, consequently, the mortality of forests worldwide (Wu et al. 2011). These climate changes challenge the main objectives of forest ecosystem management, which are to provide sustainable ecosystem services to society and to maintain the biological diversity of forests (Thom and Seidl 2015). Higher temperature and atmospheric $\mathrm{CO}_{2}$ concentration, fewer precipitations, and other climatic factors can all have important impacts on forest soil properties such as soil moisture or organic matter decomposition rate (Davidson and Janssens 2006), and thus on the biogeochemical cycles of major nutrients. In tropical ecosystems, the limiting factor of plant growth is often the availability of soil nutrients (Römheld and Kirkby 2010; Darunsontaya et al. 2012; Santiago et al. 2012). The root system is thus a major compartment that may be particularly affected by climate changes while determining plant growth in tropical conditions, but it is poorly studied given the methodological challenges (Maeght et al. 2013). The functioning of the root system is well known for its considerable plasticity and therefore its role in plant adaptation to adverse conditions, including drought (Huang et al. 1997; Eissenstat et al. 2000; Aroca 2012). Improving our knowledge of root functioning, including deep roots, is therefore especially at stake (Kell 2011; Maeght et al. 2013; Callesen et al. 2016). Concerning drought tolerance, one strategy consists in shedding roots in dry areas and rapidly growing roots in moist areas to maintain plant water status (Huang et al. 1997). In addition, moist soil layers being often deeper than dry ones, hydraulic redistribution can occur resulting in upward movement of water from deeper roots to the upper parts of the root system (Nadezhdina et al. 2010). In tropical ecosystems, in which annual evapotranspirative demand can largely exceed precipitation, water uptake by deep roots plays a major role in sustaining the evapotranspiration during the dry season (Christoffersen et al. 2014).
The functioning of the root system results in a complex combination of root-soil interactions triggered by key belowground processes such as water/nutrient acquisition, rhizodeposition or root respiration (Hinsinger et al. 2005, 2009). Hot spots of microbial activity are generated in the vicinity of roots, i.e. the so-called rhizosphere (Philippot et al. 2013; Reinhold-Hurek et al. 2015). This limited volume of soil is at the crossroad of all soil-plant interactions, and its characteristics, linked to root activities, can be drastically different from those of the bulk soil; i.e. the root-free soil volume, as reviewed by many authors. Root functioning can thus be evaluated through analyzing the properties of the rhizosphere, in comparison with those of the bulk soil, in order to better understand plant functions (e.g. Bravin et al. 2008; Hinsinger et al. 2009; Blossfeld 2013; Rewald et al. 2014; Sokolova 2015).

Most studies of the root functioning relying on rhizosphere analyses have been conducted in the topsoil, where large root densities are found and thus where rhizosphere sampling is easiest. However, the awareness of the need to study the whole of the root system, including roots at depth, has been growing recently (Maeght et al. 2013; Rewald et al. 2014). While the meta-analyses conducted by Schenk and Jackson (2002) stressed that in many ecosystems, more than $90 \%$ of the root biomass was concentrating in the top 0.5 or top $1 \mathrm{~m}$, these authors pointed out that our knowledge of deep roots was truncated as many reports did not investigate deeper soil horizons. There are notable exceptions as it has been recently shown that $60 \%$ of the fine roots in an eucalypt plantation in Brazil are located below 1-m depth (Laclau et al. 2013), while fine roots were reported to reach between 8 and $12 \mathrm{~m}$ for 2year-old genotypes (Pinheiro et al. 2016) and $17 \mathrm{~m}$ in 3.5-year old trees (Christina et al. 2011).

At the plant point of view, although this has been very little documented, roots may adjust their functioning with depth, especially their capacity for taking up nutrients (Göransson and Rosengren 2006; Göransson et al. 2007, 2008) and be more or less specialized as recently shown for eucalypt trees in Brazilian plantations (da Silva et al. 2011). These authors demonstrated that roots located at $3-\mathrm{m}$ depth had a greater potential to take up $\mathrm{Rb}^{+}$(analog of $\mathrm{K}^{+}$) and $\mathrm{Sr}^{2+}$ (analog of $\mathrm{Ca}^{2+}$ ) than those located in the topsoil, the contrary being observed for nitrate uptake. Fine root functioning has thus to be evaluated along the soil profile, not just in the topsoil. 
The $\mathrm{pH}$ of the rhizosphere can be a proxy of root functioning as long as the major cause for $\mathrm{pH}$ variation in the rhizosphere is the release of protons (or hydroxyl ions) by roots to counterbalance an excess of cations over anions (or anions over cations, respectively) taken up as nutrients (Hinsinger et al. 2003; Blossfeld 2013). Roots can thereby modify the soil $\mathrm{pH}$ in their vicinity by up to $2-3 \mathrm{pH}$ units, with considerable feedback effects on plant nutrition as a consequence of the role of $\mathrm{pH}$ as a driving factor for numerous biogeochemical processes that determine the fate (desorption/adsorption or dissolution/precipitation processes notably) and ultimately the availability of many nutrients (Hinsinger et al. 2003, 2009). In addition, roots also directly alter nutrient concentrations through their uptake and exudation activities, resulting either in steep depletion and/or accumulation of nutrients, especially for poorly-mobile nutrients such as K (Turpault et al. 2005, 2007; Calvaruso et al. 2011; Collignon et al. 2011) and $P$ (Clegg and Gobran 1997; Hinsinger et al. 2011b). Once more, such rhizosphere effects have been mostly documented for young plants growing in microcosms and, for field-grown plants, essentially for roots growing in the topsoil that are easier to sample, especially in forest ecosystems. Very fragmented information is available about the rhizosphere of roots down to $1 \mathrm{~m}$-depth (Cocco et al. 2013) and virtually no information at all is found for deeper roots.

We present here a study of the root functioning along a 4-m deep soil profile in a eucalypt (Eucalyptus grandis) plantation exhibiting a deep root system under undisturbed and reduced rainfall regimes in order to document deep root functioning through rhizosphere versus bulk soil analyses, notably $\mathrm{pH}$ and major nutrient concentrations. Our objectives were twofold: (i) evaluate how deep roots were altering soil biogeochemical properties in the rhizosphere, compared to roots in the upper horizons, and (ii) investigate how rainfall reduction was affecting these processes down to 4-m depth.

\section{Material and methods}

Study site and soil properties

The experiment was carried out on the heavily instrumented forest research site of Itatinga (São Paulo, Brazil, $23^{\circ} 02^{\prime} \mathrm{S}, 48^{\circ} 38^{\prime} \mathrm{W}$ ) owned by the University of São Paulo. Situated at $300 \mathrm{~km}$ from the sea, the study area is rather flat (slope $\leq 3 \%$ ), with an elevation of $860 \mathrm{~m}$. The region has a humid subtropical climate ranked as a $\mathrm{Cfa}$ according to the Köppen classification (Peel et al. 2007). Over the 15 years prior to this study, the mean annual rainfall was $1360 \mathrm{~mm}$ and the mean annual temperature was $19{ }^{\circ} \mathrm{C}$ with a cold and dry season occurring between June and September. The soils, called "Latosolos Vermelhos Amarelos distróficos típicos A" (Dystrophic Red-Yellow Latosol), according to the Brazilian classification (EMBRAPA 1999), are deep Ferralsols according to the FAO classification (FAO 1998), with a water table at approx. 17-m depth, developed on Cretaceous sandstone belonging to the Marilia formation / Bauru group, and exhibit little horizon differentiation (Maquère 2008). According to Laclau et al. (2010), between the soil surface and the depth of $4 \mathrm{~m}$, the main soil properties range as follows, from top (excluding the top 0-5 cm) to depth: Clay $\left(151-256 \mathrm{~g} \mathrm{~kg}^{-1}\right)$, Silt (29$\left.53 \mathrm{~g} \mathrm{~kg}^{-1}\right)$, Sand $\left(620-732 \mathrm{~g} \mathrm{~kg}^{-1}\right)$, CEC $(0.87-0.08$ $\left.\mathrm{cmol}_{\mathrm{c}} \mathrm{kg}^{-1}\right)$, organic $\mathrm{C}\left(6.4-2.0 \mathrm{~g} \mathrm{~kg}^{-1}\right), \mathrm{N}(0.47-$ $0.11 \mathrm{~g} \mathrm{~kg}^{-1}$ ).

\section{Experimental set up}

A throughfall reduction experiment was set up in 2010 with a Eucalyptus grandis clone (from the Suzano Company, SP state, Brazil). The experimental design with 6 treatments and 3 blocks was described in detail by Battie-Laclau et al. (2014). Our study was carried out in two treatments selected in one block: (i) $+\mathrm{W}$, control treatment with undisturbed rainfall; (ii) $-\mathrm{W}$, throughfall exclusion treatment. In this treatment, a gutter system was installed 2 months after planting to simulate a reduction of rainfall, through the exclusion of $37 \%$ of the throughfall. Each inter-row of this plot was equipped with two $40-\mathrm{cm}$ wide plastic sheets. The $-\mathrm{W}$ plot was mimicking the rainfall reduction forecasted for the end of the 21st century in Brazil (IPCC 2013).

The fertilization $\left(176 \mathrm{~kg} \mathrm{~K} \mathrm{ha}^{-1}, 80 \mathrm{~kg} \mathrm{~N} \mathrm{ha}^{-1}, 75 \mathrm{~kg}\right.$ $\mathrm{P} \mathrm{ha}^{-1}$ ) applied at planting in both treatments was not limiting tree growth (Laclau et al. 2009). Herbicides were applied in order to avoid the presence of other roots than eucalypt roots in the two plots. A total of 144 trees were planted at a spacing of $3 \times 2 \mathrm{~m}$ in each plot. The circumference and biomass of the trees in April 2015 are given in Supplementary material (Table S1). The stocking density in our experiment was 1666 tree ha $^{-1}$ without tree mortality. 
Monitoring of soil water contents and foliar potentials in this experiment showed that the low soil water availability in $-\mathrm{W}$ led to a sharp decrease in leaf gas exchange and biomass production, relative to $+\mathrm{W}$, during dry periods from 2 years after planting onward (Battie-Laclau et al. 2014; Christina et al. 2015; Epron et al. 2016). Time series of volumetric soil water content (SWC) are shown in Supplementary material (Figure S1) along the soil profile down to a depth of $4 \mathrm{~m}$. SWCs were measured from March 2015 to October 2015 at half-hourly intervals, with CS616 probes (Campbell Scientific Inc., Logan, UT, USA), installed at 6 depths down to $4 \mathrm{~m}(0.15,0.5,1,2,3,4 \mathrm{~m}$; three probes at different distances from trees per depth). In both treatments, rainfall events led to large variations of SWC in the upper $1 \mathrm{~m}$ (from 6.5 to $19 \% \mathrm{in}+\mathrm{W}$ and from 5.5 to $14 \%$ in $-W$ ). Below $1 \mathrm{~m}$ depth, SWCs were much less influenced by rainfall events. In $+\mathrm{W}$, there was a difference of about $3 \%$ between mean SWC at a depth of $2 \mathrm{~m}$ and mean SWC at a depth of 3 and $4 \mathrm{~m}$, and the end of the rainy period (March to June) was marked by a slight decrease in SWC at the depth of $4 \mathrm{~m}$. By contrast, SWCs between the depths of 2 and $4 \mathrm{~m}$ in -W remained around $10 \%$ over the study period.

\section{Soil sampling and analyses}

Soil samples were collected between May and June 2015. A $1.5-\mathrm{m}$ wide square pit was dug in the 3$\mathrm{m}$ wide inter-row of the exclusion and control plots. The pits were dug by hand, as this soil is very cohesive and never provokes any wall collapse. The security of individuals was ensured by a scaffolding system installed in the pit, when reaching a depth greater than $2 \mathrm{~m}$. Rhizosphere and bulk soil were sampled in layers located at 10 depths from the surface, down to a depth of $4 \mathrm{~m}$ (Fig. 1). At each depth, the four quarters of the pit were collected separately during the excavation in order to create four pseudo-replicates (Fig. 1). During the excavation, at each depth, the soil of each replicate was placed in a separate wheelbarrow; all roots and their adhering soil (operationally-defined rhizosphere) were collected in a plastic bag. The rhizosphere was then separated from roots using a paintbrush. In order to be sure not to collect soil that was close to roots, the bulk soil was sampled from root-free zones at various locations on the two walls of each quarter of the pit, at the end of the excavation of each soil depth, and ultimately collected in a $40-\mathrm{cm}^{3}$ plastic vial.
Rhizosphere and bulk soil samples were air-dried at room temperature and sieved at $2 \mathrm{~mm}$ to remove root debris and homogenize the soil prior to analyses. Major nutrient $(\mathrm{P}, \mathrm{K}, \mathrm{Ca}$ and $\mathrm{Mg}$ ) concentrations and $\mathrm{pH}$ were determined at the Soil Department in UNESP (Universidade Estadual Paulista, in Botucatu, Brazil). Major nutrients ( $\mathrm{P}, \mathrm{K}, \mathrm{Ca}$ and $\mathrm{Mg}$ ) were extracted using a 1:1 mixture of an anion exchange resin to assess the available pool of phosphate (strong base type, 2050 mesh beads, Amberlite IRA-400) and a cation exchange resin to assess the exchangeable pool of $\mathrm{K}, \mathrm{Ca}$ and $\mathrm{Mg}$ (strong acid type, granulometry 20-50 mesh, Amberlite IR-120). A soil suspension prepared with $2.5 \mathrm{~g}$ of soil mixed with $25 \mathrm{~cm}^{3}$ deionized water and $2.5 \mathrm{~cm}^{3}$ of extracting resin was shaken for $16 \mathrm{~h}$ (van Raij and Quaggio 2001). After the elution of the resins, the concentrations of the extracted cations were determined by Flame Atomic Absorption spectrometer Perkin Elmer 2380 (United States) and the concentration of available phosphorus was determined using a spectrophotometer Femto 600plus (Brazil). For pH measurements, a soil suspension was prepared at a 1:5 soil mass:extracting volume ratio according to the NF ISO 10390 standard, using $0.01 \mathrm{M} \mathrm{CaCl}_{2}$ as a background electrolyte that yields a better stability of $\mathrm{pH}$ reading. The difficulty of collecting a large quantity of rhizosphere at depth required to slightly adapt the NF ISO 10390 protocol using only $2 \mathrm{~g}$ of soil in $10 \mathrm{~cm}^{3}$ extracting solution, and a micro $\mathrm{pH}$ electrode (SenTix Mic-D-300x300).

Subsamples of soil were used for determining pseudo-total $\mathrm{K}$ after grinding to $<0.2 \mathrm{~mm}$, at the UMR Eco\&Sols in Montpellier, France. Pseudo-total K concentration (thereafter called $\mathrm{K}_{\mathrm{tot}}$ ) was determined for the bulk soil only with a composite sample of the four replicates at each depth for both treatments. The extractions were done with $1: 1$ concentrated $\mathrm{HNO}_{3}$ and $\mathrm{HCl}$ (aqua regia), not with $\mathrm{HF}$; the total $\mathrm{K}$ is thereby underestimated in our results, hence called pseudototal $\mathrm{K}$.

\section{Root sampling and measurements}

Firstly, fine roots were sampled down to a depth of $2 \mathrm{~m}$ using a $4.5 \mathrm{~cm}$ diameter manual auger at four positions relative to the trees in both treatments $(+\mathrm{W},-\mathrm{W})$ and in the three blocks, between February and April 2015. Secondly, a $7 \mathrm{~cm}$ diameter mechanical auger was used to collect fine roots down to the watertable at $17 \mathrm{~m}$ deep, 
Fig. 1 Profile view of the pit, showing the 10 layers of soil. Plan view of the pit, showing the 4 replicate positions and the location of the pit in the eucalypt inter-row

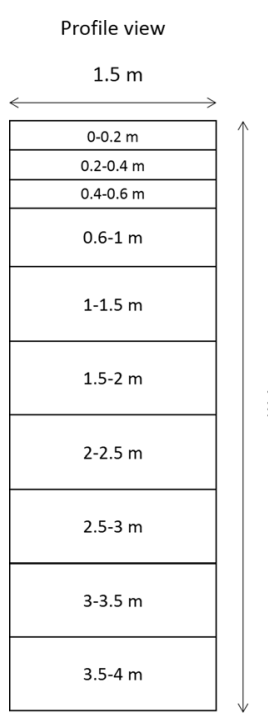

Plan view

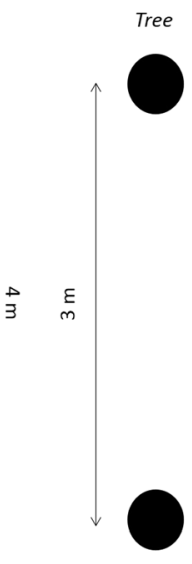

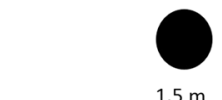
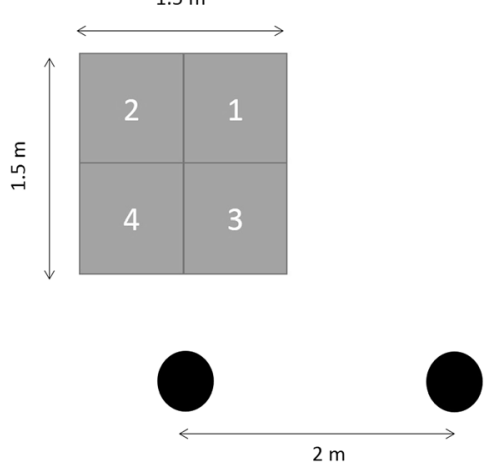

following the methodology used by Christina et al. (2011). Here we present the results of fine root biomass down to 4-m depth. The roots were carefully washed in a $0.5 \mathrm{~mm}$ mesh sieve. Dead roots were discarded and only living roots (light-coloured and flexible) were scanned, and root length was estimated using the WinRHIZO Version Pro V.2013c software (Regent Instruments, QC, Canada). Roots were then dried at $65^{\circ} \mathrm{C}$ to constant weight. For each soil layer, the ratio between surface area and dry mass of fine roots was used to estimate the specific root area (SRA, $\mathrm{cm}^{2} \mathrm{~g}^{-1}$ ) (Maurice et al. 2010). Root mass densities (RMD, g $\mathrm{dm}^{-3}$ ) were calculated by dividing the dry mass of fine roots by the volume of the sampled soil. Root Area Density (RAD, $\mathrm{cm}^{2} \mathrm{dm}^{-3}$ ) was obtained by multiplying the RMD with the SRA.

\section{Statistical analyses}

The goal was to assess significant differences between soil compartments (rhizosphere/bulk soil) in each treatment $(+\mathrm{W} /-\mathrm{W})$ and at each depth. We investigated the autocorrelation of the depth residues when using a simple linear model and a mixed effects model with two fixed factors (compartment and treatment), one random factor (replicates) and one predictive factor (depth). No relevant predictive function for depth was found (AR(1): autoregressive model that specifies that the output variable depends linearly on its own previous values and on a stochastic term; corEXP: exponential spatial correlation structure). It thus appeared more relevant to use a linear model with four main factors (treatment, depth, compartment, replicates) and their interactions to fit our results. We checked the normal distribution of the residues for the chosen model. To investigate the interaction between each factor, onefactor analysis of variance (ANOVA) was used on the corresponding subset of data. Before analysis, all $\mathrm{pH}$ values were converted to $\mathrm{H}_{3} \mathrm{O}^{+}$concentrations. Statistical analyses were conducted with the $\mathrm{R}$ software (version 3.2.2). For the graphical representations, the mean values were calculated from our replicates $(n=4)$, as well as standard errors.

\section{Results}

Bulk soil chemical properties

The available $\mathrm{P}$ concentration in the bulk soil was influenced by the throughfall exclusion treatment $(p<0.05)$ but not significantly influenced by depth. The values were fairly low throughout the profile though, ranging between 3.1 and $4.2 \mathrm{mg} \mathrm{kg}^{-1}$ (Fig. 2a). The highest difference between the two treatments was found at the depth of $0.4-0.6 \mathrm{~m}$. Without taking into account this single depth in the ANOVA analysis, the influence of the treatment disappeared. The concentrations of available $\mathrm{P}$ in the bulk soils were almost constant along the soil profile down to a depth of $4 \mathrm{~m}$.

The exchangeable $\mathrm{K}$ concentration in the bulk soil was not influenced by the throughfall exclusion 


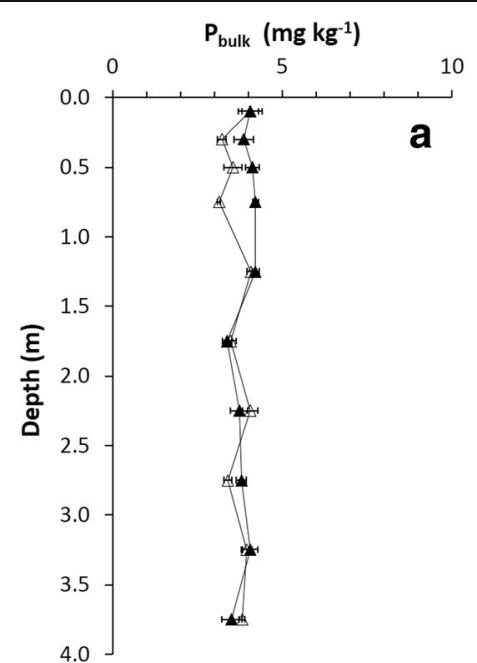

Fig. 2 Available $\mathrm{P}$ values obtained for the bulk soil (triangles) along the soil profile in the $+\mathrm{W}$ (full symbol) and $-\mathrm{W}$ treatment (open symbol) (a); Comparison of the values of available $\mathrm{P}$

treatment, as we did not find any significant difference between the control and exclusion plots according to one-factor ANOVA analysis. However, the K concentration in the bulk soil was significantly altered with depth (at $p<0.001$ ). The vertical distribution of the concentrations of exchangeable $\mathrm{K}$ in the bulk soil along the soil profile followed a power function for both treatments, with a $R^{2}>0.7$ (Fig. 3a). There was a steep, about two-fold decrease of exchangeable $\mathrm{K}$ concentration with depth in the top first meter of soil (from 0.55 to $0.25 \mathrm{mg} \mathrm{kg}^{-1}$ ); the decrease was then more progressive and steady between 1 and $4 \mathrm{~m}$ of soil depth, exhibiting again a two-fold decrease. The values of $\mathrm{K}_{\mathrm{tot}}$ in the bulk
$P\left(\mathrm{mg} \mathrm{kg}^{-1}\right)-W$

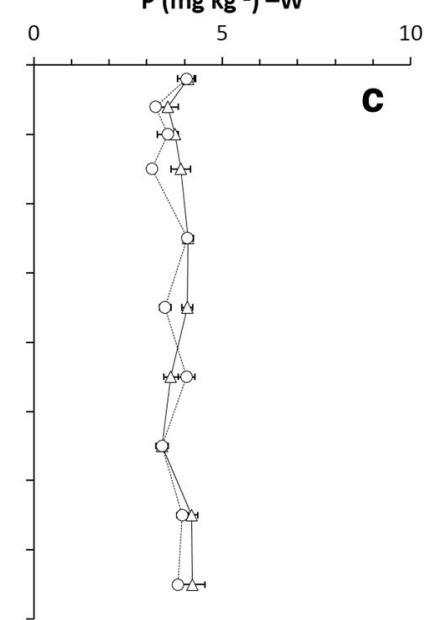

obtained in the bulk soil (triangles) with those obtained in the rhizospheres (circles) in the $+\mathrm{W}$ (b) and $-\mathrm{W}$ treatments (c). $n=4$ for the standard errors, B stands for bulk soil and R for rhizosphere

soil ranged from 60 to $100 \mathrm{mg} \mathrm{kg}^{-1}$ (with an outlier value of $148 \mathrm{mg} \mathrm{kg}^{-1}$ at the depth of $1 \mathrm{~m}$ in the control treatment) in both $+\mathrm{W}$ and $-\mathrm{W}$ treatments (Figure $\mathrm{S} 2$ ). The values of $\mathrm{K}_{\mathrm{tot}}$ in the bulk soil were not influenced by throughfall exclusion or by soil depth.

As for exchangeable $\mathrm{K}$, the $\mathrm{pH}$ of the bulk soil was not influenced by throughfall exclusion, as we did not find any significant difference between the control and exclusion plots according to one-factor ANOVA analysis. However, the $\mathrm{pH}$ in the bulk soil was significantly altered with soil depth (at $p<0.001)$. The significant linear regression $\left(R^{2}>0.96\right)$ between $\mathrm{pH}$ and soil depth found for both control and exclusion treatments
Fig. 3 Bulk soil exchangeable K concentration values (a), $\mathrm{pH}$ values (b) along the soil profile in the $+\mathrm{W}$ (full symbol) and $-\mathrm{W}$ treatment (open symbol). $n=20$ for the regressions, $i=4$ for the standard errors, B stands for bulk soil

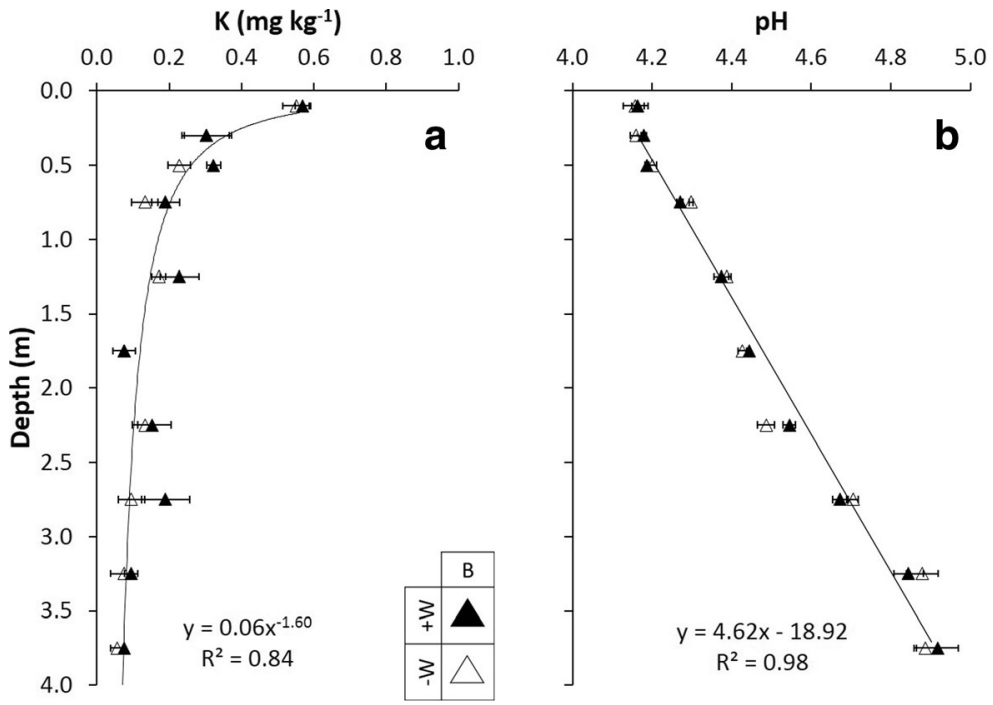


(Fig. 3b) was indicative of a general acidification along the soil profile, from a mean value around 4.90 at depths of $3.5-4 \mathrm{~m}$ to a mean value of 4.16 within the topsoil $(0-0.2 \mathrm{~m})$.

A large proportion of our bulk soil samples reached the limits of detection of the Atomic Absorption Spectrometer, which were $1.12 \mathrm{mg} \mathrm{kg}^{-1}$ for $\mathrm{Ca}$ and $0.56 \mathrm{mg} \mathrm{kg}^{-1}$ for $\mathrm{Mg}$. An overall effect of the exclusion treatment or soil depth was impossible to detect (Table S2). Concerning available $\mathrm{Ca}$, all the values of the bulk soil were $\leq 2.24 \mathrm{mg} \mathrm{kg}^{-1}$ (determination threshold) in both treatments. Concerning available $\mathrm{Mg}$, in the $+\mathrm{W}$ treatment all the values were $\leq 1.12 \mathrm{mg} \mathrm{kg}^{-1}$ (determination threshold), except the four replicates of the topsoil (in the $0-0.2-\mathrm{m}$ soil layer). In the $-\mathrm{W}$ treatment, all the values were $\leq 1.12 \mathrm{mg} \mathrm{kg}^{-1}$, except one replicate of the topsoil.

Rhizosphere chemical properties

Available $\mathrm{P}$ concentrations within the rhizosphere (Fig. 2b, c) ranged between 3.31 and $4.06 \mathrm{mg} \mathrm{kg}^{-1}$ for the $+\mathrm{W}$ treatment and between 3.22 and $4.21 \mathrm{mg} \mathrm{kg}^{-1}$ for the $-\mathrm{W}$ treatment. Available $\mathrm{P}$ was lower in the rhizosphere than in the bulk soil in the throughfall exclusion treatment (at $p<0.05$ ), but the differences were not significant in the $+\mathrm{W}$ treatment. Soil depth did not influence significantly rhizosphere $P$ availability. As for the bulk soil, the $0.4-0.6 \mathrm{~m}$ soil layer exhibited the highest difference in $\mathrm{P}$ availability between rhizosphere and bulk soil samples.

The concentrations of exchangeable $\mathrm{K}$ in the rhizosphere were significantly higher than those of the bulk soil in both $+\mathrm{W}$ and $-\mathrm{W}$ treatments $(p<0.001)$. However, this difference was higher in the $-\mathrm{W}$ treatment, notably below the depth of $2 \mathrm{~m}$ (Fig. $4 \mathrm{a}, \mathrm{c}$ ).

The soil $\mathrm{pH}$ was significantly influenced by soil depth within the rhizosphere, as observed in the bulk soil $(p<0.001)$. In contrast with the bulk soil, the $\mathrm{pH}$ of the rhizosphere was also significantly affected by the throughfall exclusion, along the soil profile (at $p<0.1$ ). The concentration in $\mathrm{H}_{3} \mathrm{O}^{+}$in the rhizosphere was significantly greater than that of the bulk soil in the exclusion plot whereas no such rhizosphere acidification was found in the control plot (Fig. $4 b$ and d).

As for bulk soils, most of our samples reached the limit of detection of the Atomic Absorption Spectrometer for the concentrations of available $\mathrm{Ca}$ and $\mathrm{Mg}$, except in the topsoil, and it was thus impossible to detect a throughfall exclusion, soil depth or rhizosphere effect (Table S2). Concerning available $\mathrm{Ca}$ in the $+\mathrm{W}$ treatment, all the values were $\leq 2.24 \mathrm{mg} \mathrm{kg}^{-1}$, except the four replicates of the topsoil (depth of $0-0.2 \mathrm{~m}$ ). In the $-\mathrm{W}$ treatment, all the values were $\leq 2.24 \mathrm{mg} \mathrm{kg}-1$, but one replicate at the depth of $0-0.2 \mathrm{~m}\left(3.36 \mathrm{mg} \mathrm{kg}^{-1}\right)$. Concerning available $\mathrm{Mg}$, in the $+\mathrm{W}$ treatment all the values were $\leq 1.12 \mathrm{mg} \mathrm{kg}^{-1}$ except the four replicates of the topsoil (depth of $0-0.2 \mathrm{~m}$ ). In the $-\mathrm{W}$ treatment, all the values were $\leq 1.12 \mathrm{mg} \mathrm{kg}^{-1}$ except the four replicates of the topsoil (depth of $0-0.2 \mathrm{~m}$ ), three replicates at the depth of 0.2-0.4 m and one replicate at the depth of $0.6-1 \mathrm{~m}$.

Influence of soil depth on the difference between rhizosphere and bulk soil chemical properties

Changes in rhizosphere $\mathrm{pH}$ relative to the bulk soil along the 4-m deep soil profiles were treatment-dependent. In the $+\mathrm{W}$ treatment (Fig. 5a), the rhizosphere $\mathrm{pH}$ was higher than the bulk soil $\mathrm{pH}$ in the topsoil $(+0.22 \mathrm{pH}$ unit at the depth of $0-0.2 \mathrm{~m}$ ), and a slight acidification of the rhizosphere occurred below the depth of $1 \mathrm{~m}$ with a maximum acidification between 3 and $4 \mathrm{~m}$ depths $(-0.11 \mathrm{pH}$ unit). In the $-\mathrm{W}$ treatment, rhizosphere acidification occurred along the whole soil profile (Fig. $5 \mathrm{c}$ ). The rhizosphere experienced the highest acidification $(>0.2 \mathrm{pH}$ unit) both in the topsoil and below the depth of $2.5 \mathrm{~m}$, whereas the acidification in the intermediate layers was around $0.08 \mathrm{pH}$ unit. Given the logarithmic nature of $\mathrm{pH}$, it however makes more sense to assess the difference between rhizosphere and bulk soil in terms of changes of $\mathrm{H}_{3} \mathrm{O}^{+}$concentration (Fig. 5b). A $0.2 \mathrm{pH}$ unit decrease both in the topsoil and in the soil layers below the depth of $2.5 \mathrm{~m}$ did not imply the same amount of protons, starting from a bulk soil $\mathrm{pH}$ around 4.4 within the topsoil or around 4.7 below $2.5 \mathrm{~m}$ deep. Therefore, a much higher amount of protons $\left(4.5910^{-5} \mathrm{~mol}\right.$ in the topsoil instead of $<1.2510^{-5}$ mol below the depth of $2.5 \mathrm{~m}$, on a per $\mathrm{dm}^{3}$ of soil solution basis) was needed within the topsoil to yield a $\mathrm{pH}$ shift of $0.2 \mathrm{pH}$ unit. The amount of protons released in the rhizosphere was thus quite homogenous along the soil profile in the $-\mathrm{W}$ treatment (around $110^{-5} \mathrm{~mol}$, on a per $\mathrm{dm}^{3}$ of soil solution basis), except in the topsoil where it increased by a factor of 4.5 .

In the $+\mathrm{W}$ treatment, exchangeable $\mathrm{K}$ concentrations increased in the rhizosphere relative to the bulk soil, with a peak in the topsoil, and then a lesser increase with 

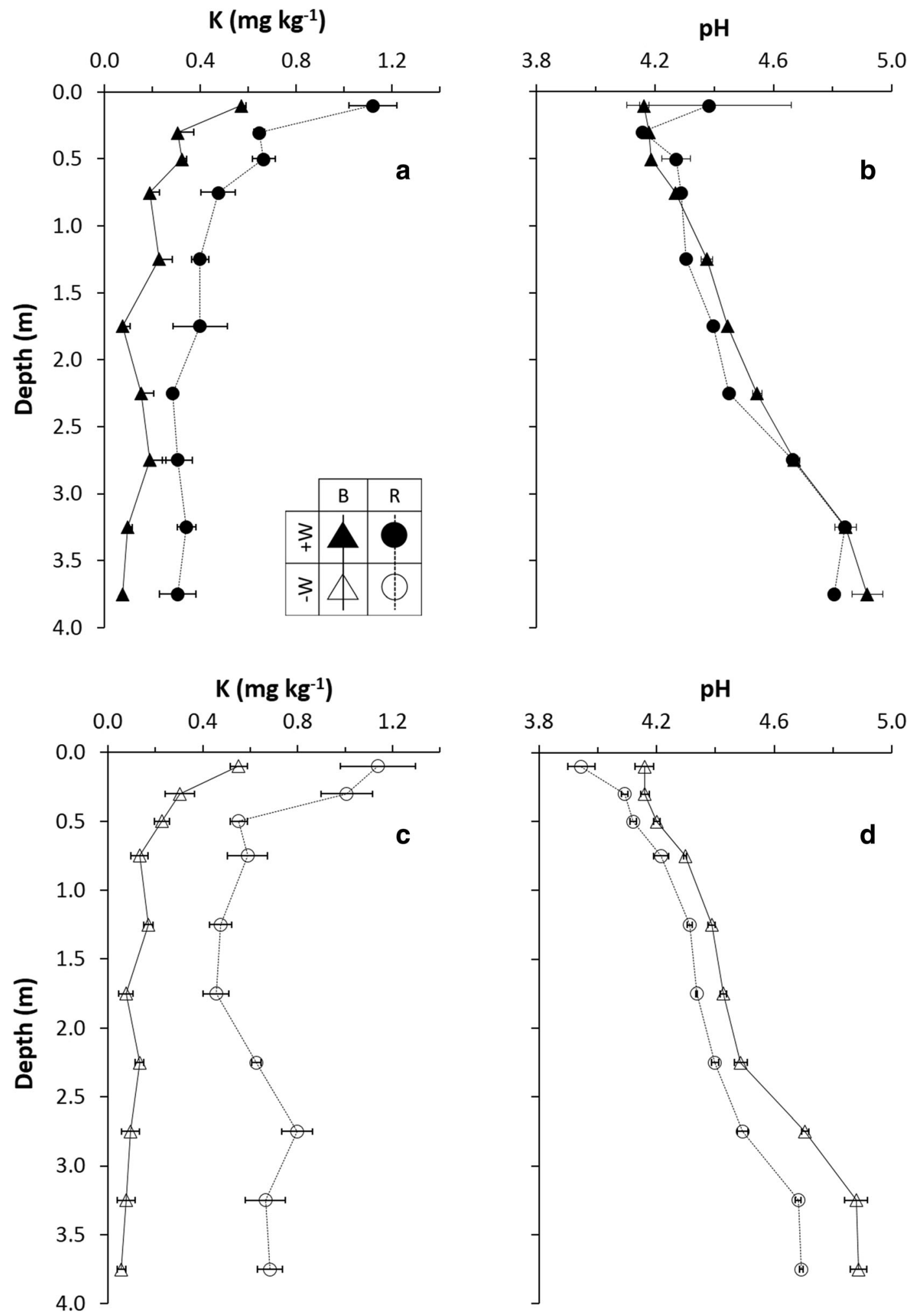

Fig. 4 Comparison of the values obtained in the bulk soil (triangles) with those obtained in the rhizospheres (circles) for the exchangeable $\mathrm{K}$ (a and $\mathbf{c})$ and the $\mathrm{pH}(\mathbf{b}$ and $\mathbf{d})$ in the $+\mathrm{W}$ (a

and b) and $-\mathrm{W}$ treatment (c and d). $n=4$ for the standard errors, B stands for bulk soil and $\mathrm{R}$ for rhizosphere 

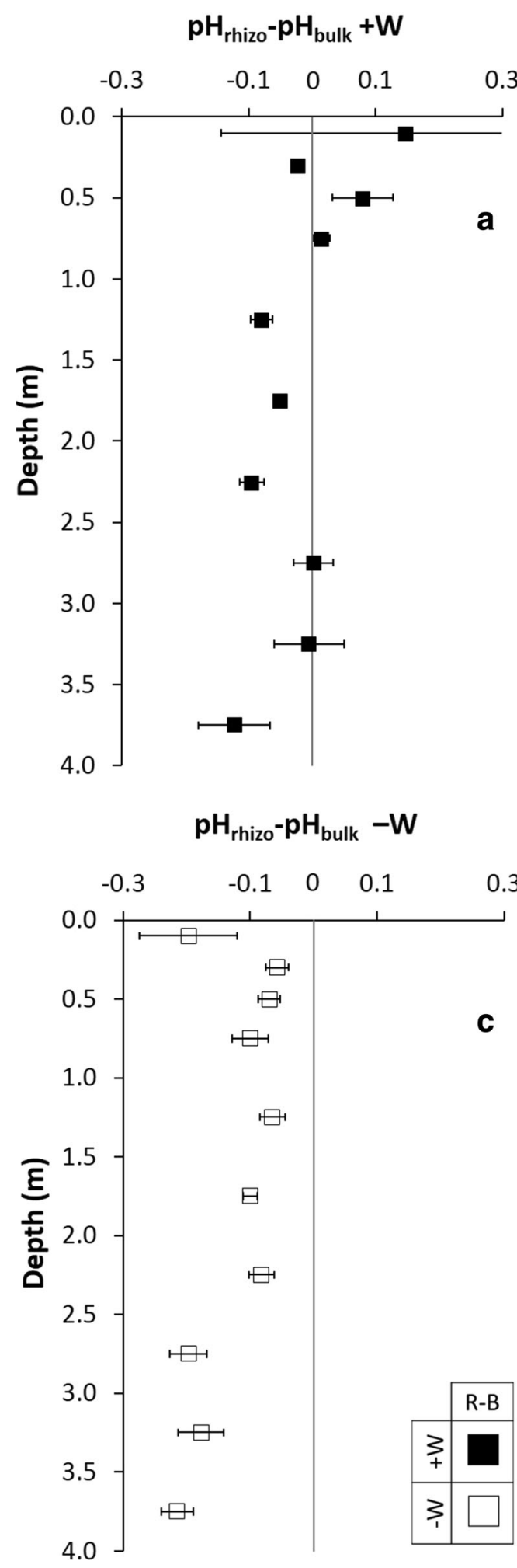

Fig. 5 Difference of $\mathrm{pH}$ between rhizosphere and bulk soil along the soil profile in the $+\mathrm{W}$ (a) and in the $-\mathrm{W}$ treatment (c); Difference of concentration between rhizosphere and bulk soil in the + $\mathrm{W}$ (full symbol) and the -W treatment (open symbol) for $\mathrm{H}_{3} \mathrm{O}^{+}(\mathbf{b})$

$\left[\mathrm{H}_{3} \mathrm{O}^{+}\right]_{\text {rhizo }}-\left[\mathrm{H}_{3} \mathrm{O}^{+}\right]_{\text {bulk }}\left(\mathrm{mol} \mathrm{L}^{-1}\right)$
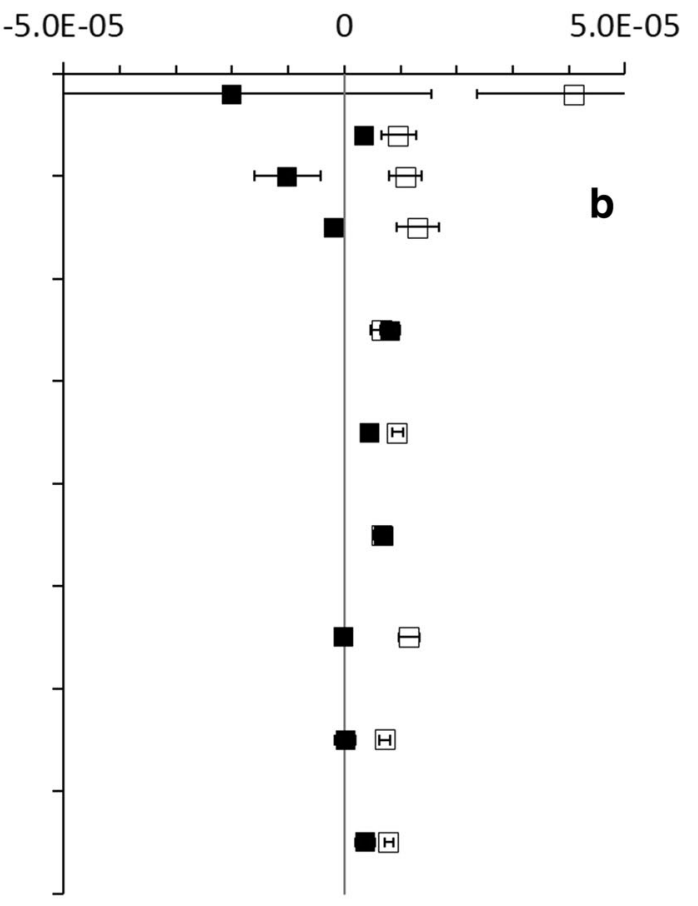

$\mathrm{K}_{\text {rhizo }}-\mathrm{K}_{\text {bulk }}\left(\mathrm{mg} \mathrm{kg}^{-1}\right)$

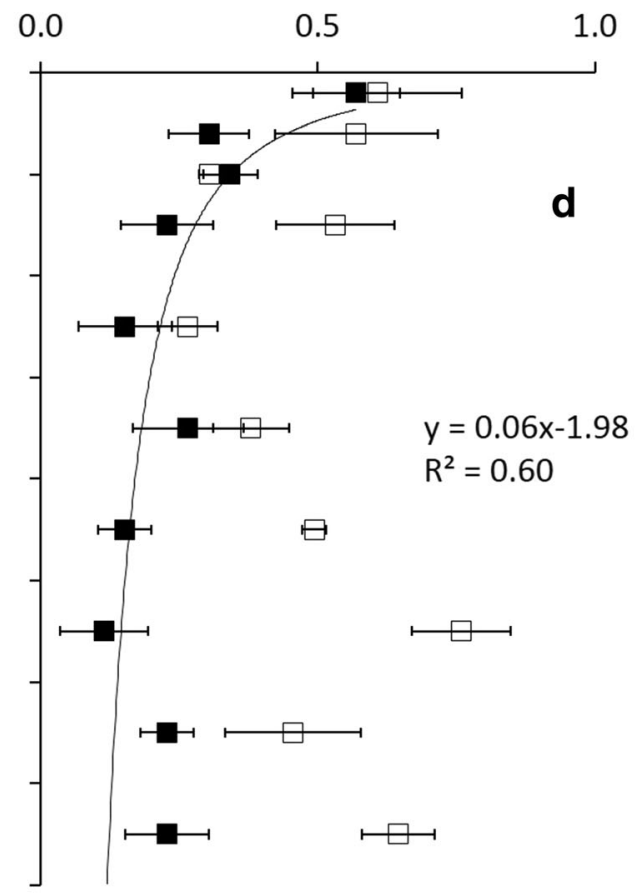

and $\mathrm{K}^{+}(\mathbf{d})$. Power equation stands for $+\mathrm{W}$ data in $(\mathbf{d}), n=4$ for the standard errors and R-B stands for the difference between rhizosphere and bulk soil values 
soil depth (Fig. 5d). The difference between exchangeable $\mathrm{K}$ concentrations in the bulk soil and in the rhizosphere was significantly influenced by soil depth $(p<0.001)$. Mean differences between the rhizosphere and the bulk soil could be modeled by a power function $\left(R^{2}>0.56\right)$, with a decrease from the topsoil $\left(0.6 \mathrm{mg} \mathrm{kg}^{-1}\right)$ to the depth of $4 \mathrm{~m}\left(0.2 \mathrm{mg} \mathrm{kg}^{-1}\right)$. The increase in exchangeable $\mathrm{K}$ concentration in the rhizosphere relative to the bulk soil showed in the upper soil layers of the $+\mathrm{W}$ treatment was also observed in the $-\mathrm{W}$ treatment. In contrast, below a depth of $1 \mathrm{~m}$, the difference between the rhizosphere and the bulk soil increased in the $-\mathrm{W}$, reaching maximal values below a depth of $2 \mathrm{~m}\left(0.7 \mathrm{mg} \mathrm{kg}^{-1}\right)$. At

Table 1 Estimation, per soil layer, of the root mass density (RMD), the root area density (RAD), the volume of rhizosphere $\left(\mathrm{V}_{\text {rhizo }}\right)$, the percentage of rhizosphere volume among total soil such depths, the increase in $\mathrm{K}$ availability within the rhizosphere was as large as in the topsoil for this treatment.

For both treatments, we computed the stocks of exchangeable $\mathrm{K}$ and $\mathrm{K}_{\text {tot }}$ in the bulk soil and the rhizosphere for each soil layer and for the whole 4-m soil profile taking into account the fine root distribution (Table 1). The fine root dry mass density (RMD), the root area density (RAD) and hence the volume of the rhizosphere sharply decreased with soil depth but still remained substantial down to a depth of $4 \mathrm{~m}$ in both treatments. Consequently, the stock of exchangeable $\mathrm{K}$ in the rhizosphere decreased with soil depth, amounting to a total of 1.42 and $2.03 \mathrm{~kg} \mathrm{ha}^{-1}$ in

volume $\left(\mathrm{V}_{\text {rhizo }} / \mathrm{V}_{\text {tot }}\right)$, the stock of pseudo-total $\mathrm{K}\left(\mathrm{K}_{\text {tot }}\right)$ and exchangeable $\mathrm{K}\left(\mathrm{K}_{\mathrm{exch}}\right)$ within the bulk soil and the rhizosphere

\begin{tabular}{|c|c|c|c|c|c|c|c|c|c|c|}
\hline Treat. & $\begin{array}{l}\text { Layers } \\
\mathrm{cm}\end{array}$ & $\begin{array}{l}\text { RMD } \\
\mathrm{g} \mathrm{dm}^{-3}\end{array}$ & $\begin{array}{l}\text { RAD } \\
\mathrm{cm}^{2} \mathrm{dm}^{-3}\end{array}$ & $\begin{array}{l}\mathrm{V}_{\text {rhizo }} \\
\mathrm{m}^{3} \mathrm{ha}^{-1}\end{array}$ & $\begin{array}{l}\mathrm{V}_{\text {rhizo }} / \mathrm{V}_{\text {tot }} \\
\%\end{array}$ & $\begin{array}{l}\mathrm{K}_{\text {exch bulk }} \\
\mathrm{kg} \mathrm{ha}^{-1}\end{array}$ & $\begin{array}{l}\mathrm{K}_{\text {tot }} \text { bulk } \\
\mathrm{kg} \mathrm{ha}^{-1}\end{array}$ & $\begin{array}{l}\mathrm{K}_{\text {exch }} \text { rhizo } \\
\mathrm{kg} \mathrm{ha}^{-1}\end{array}$ & $\begin{array}{l}\mathrm{K}_{\text {tot }} \text { rhizo } \\
\mathrm{kg} \mathrm{ha}^{-1}\end{array}$ & $\begin{array}{l}\mathrm{K}_{\text {exch }} \text { rhizo-bulk } \\
\mathrm{kg} \mathrm{ha}^{-1}\end{array}$ \\
\hline \multirow[t]{11}{*}{$+\mathrm{W}$} & $0-20$ & 0.96 & 188.05 & 376.09 & 18.80 & 1.59 & 202 & 0.59 & 38 & 0.29 \\
\hline & $20-40$ & 0.22 & 55.79 & 111.58 & 5.58 & 0.85 & 167 & 0.10 & 9 & 0.05 \\
\hline & $40-60$ & 0.25 & 55.15 & 110.30 & 5.51 & 0.90 & 212 & 0.10 & 12 & 0.05 \\
\hline & $60-100$ & 0.27 & 54.50 & 218.01 & 5.45 & 1.06 & 490 & 0.14 & 27 & 0.09 \\
\hline & $100-150$ & 0.04 & 48.16 & 240.81 & 4.82 & 1.59 & 697 & 0.13 & 34 & 0.06 \\
\hline & $150-200$ & 0.05 & 57.47 & 287.34 & 5.75 & 0.53 & 593 & 0.16 & 34 & 0.13 \\
\hline & $200-250$ & 0.04 & 28.42 & 142.10 & 2.84 & 1.06 & 629 & 0.06 & 18 & 0.03 \\
\hline & $250-300$ & 0.10 & 23.36 & 116.78 & 2.34 & 1.33 & 490 & 0.05 & 11 & 0.02 \\
\hline & $300-350$ & 0.05 & 18.29 & 91.46 & 1.83 & 0.66 & 594 & 0.04 & 11 & 0.03 \\
\hline & $350-400$ & 0.02 & 17.70 & 88.48 & 1.77 & 0.53 & 601 & 0.04 & 11 & 0.03 \\
\hline & Total 0-400 & & & & & 10.12 & 4676 & 1.42 & 204 & 0.77 \\
\hline \multirow[t]{11}{*}{$-\mathrm{W}$} & $0-20$ & 1.14 & 240.05 & 480.10 & 24.00 & 1.54 & 209 & 0.77 & 50 & 0.40 \\
\hline & $20-40$ & 0.27 & 92.97 & 185.95 & 9.30 & 0.85 & 198 & 0.26 & 18 & 0.18 \\
\hline & $40-60$ & 0.30 & 86.22 & 172.43 & 8.62 & 0.64 & 276 & 0.13 & 24 & 0.08 \\
\hline & $60-100$ & 0.32 & 79.46 & 317.82 & 7.95 & 0.74 & 539 & 0.26 & 43 & 0.20 \\
\hline & $100-150$ & 0.05 & 70.12 & 350.61 & 7.01 & 1.20 & 448 & 0.23 & 31 & 0.15 \\
\hline & $150-200$ & 0.05 & 39.15 & 195.77 & 3.92 & 0.53 & 520 & 0.12 & 20 & 0.10 \\
\hline & $200-250$ & 0.10 & 20.39 & 101.93 & 2.04 & 0.93 & 695 & 0.09 & 14 & 0.07 \\
\hline & $250-300$ & 0.04 & 15.50 & 77.49 & 1.55 & 0.66 & 650 & 0.09 & 10 & 0.08 \\
\hline & $300-350$ & 0.06 & 10.61 & 53.05 & 1.06 & 0.53 & 644 & 0.05 & 7 & 0.04 \\
\hline & $350-400$ & 0.06 & 6.15 & 30.73 & 0.61 & 0.40 & 515 & 0.03 & 3 & 0.03 \\
\hline & Total $0-400$ & & & & & 8.02 & 4694 & 2.03 & 221 & 1.33 \\
\hline
\end{tabular}

The volume of rhizosphere has been calculated from the RAD values and using a soil density of $1.4 \mathrm{~g} \mathrm{~kg}^{-1}$ and a rhizosphere thickness of $1 \mathrm{~cm}$. The stock of $\mathrm{K}_{\mathrm{tot}}$ in the rhizosphere was calculated by multiplying the rhizosphere volume by the $\mathrm{K}_{\mathrm{tot}}$ content measured in the bulk soil. The accumulation of exchangeable $\mathrm{K}$ within the rhizosphere $\left(\mathrm{K}_{\mathrm{exch}}\right.$ rhizo-bulk) was calculated by multiplying the rhizosphere volume by the difference of $\mathrm{K}_{\text {exch }}$ content in the rhizosphere relative to the bulk soil 


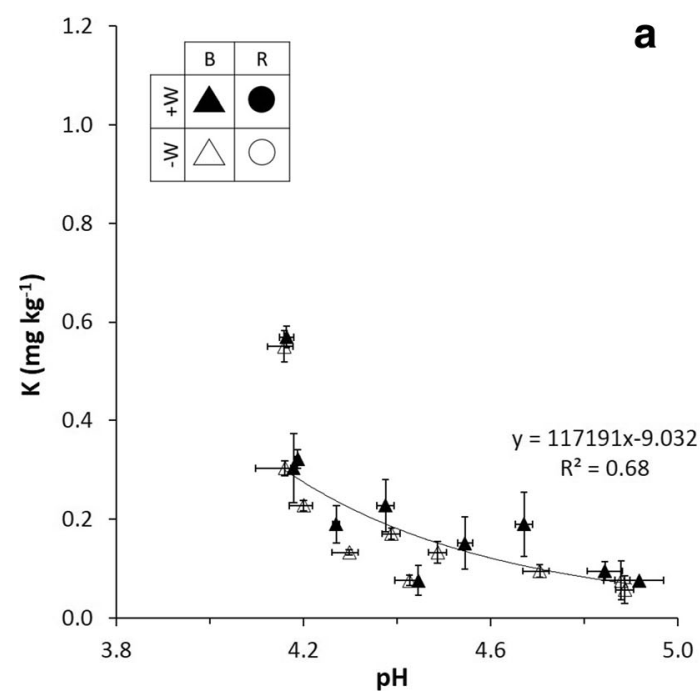

Fig. 6 Relationship between exchangeable $\mathrm{K}$ concentration and $\mathrm{pH}$ for both treatments ( $+\mathrm{W}=$ full symbol; $-\mathrm{W}=$ open symbol) for the bulk soil (a) and the rhizosphere (b). $n=4$ for the standard

the whole soil profile of $+\mathrm{W}$ and $-\mathrm{W}$ treatments, respectively. The accumulation of exchangeable $\mathrm{K}$ ( $\mathrm{K}_{\text {exch }}$ rhizo-bulk) in the rhizosphere showed the same pattern, amounting to a total of 0.77 and $1.33 \mathrm{~kg} \mathrm{ha}^{-1}$ in the whole soil profile of $+\mathrm{W}$ and $-\mathrm{W}$ treatments, respectively (Table 1).

\section{Relationship between soil $\mathrm{pH}$ and $\mathrm{K}$ availability}

In the bulk soil, the concentration of exchangeable $\mathrm{K}$ was negatively correlated with the $\mathrm{pH}$ whatever the treatment (Fig. 6a). The relationship between $\mathrm{pH}$ and exchangeable $\mathrm{K}$ concentration was not significant in the rhizosphere and clearly different between the two treatments (Fig. 6b). The concentration of exchangeable K within the rhizosphere was thus not fully explained by the $\mathrm{pH}$ as observed in the bulk soil.

\section{Discussion}

\section{Acidification of the rhizosphere}

The combined action of a number of processes can explain the differences of $\mathrm{pH}$ observed between the rhizosphere and the bulk soil (Hinsinger et al. 2003). However, the leading process is commonly the imbalance between nutrient cation and anion uptake by plants. Thereby, $\mathrm{pH}$ decrease in the rhizosphere mainly results from the release

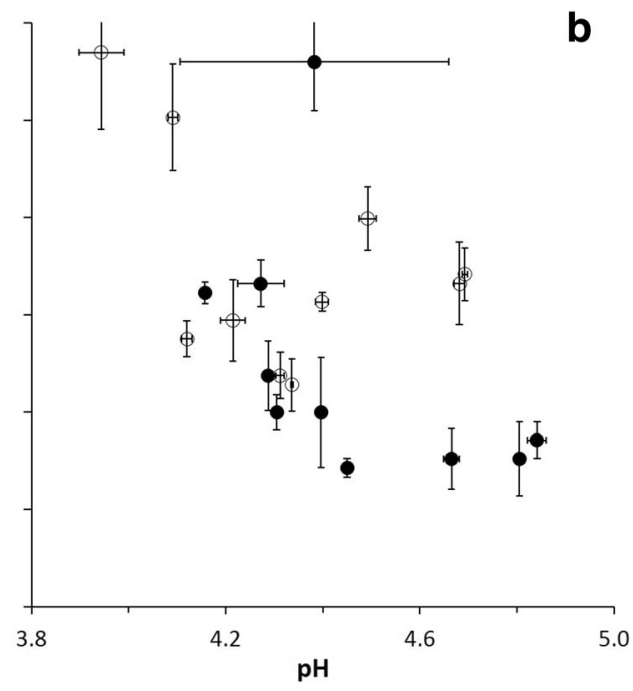

errors, $n=20$ for the regression combining the two treatments ( $+\mathrm{W}$ and $-\mathrm{W}$ ) and calculated on the average values in each soil layer in (a), B stands for bulk soil and R for rhizosphere

of protons by roots to counterbalance an excess of cations over anions taken up. According to our results, the throughfall exclusion treatment increased the acidification of the rhizosphere, which could have resulted from higher amounts of cations, notably $\mathrm{K}$, taken up in the throughfall exclusion treatment than in the control treatment. Although an adequate $\mathrm{K}$ nutrition greatly enhances the stomatic control of water loss of $E$. grandis trees in response to changes in soil water availability (Battie-Laclau et al. 2014) and stem biomass production (Battie-Laclau et al. 2016), destructive measurements in our experiments showed that $\mathrm{K}$ contents in the trees were not higher in $-\mathrm{W}$ than in $+\mathrm{W}$ (unpublished data), and therefore differences in K uptake cannot explain the acidification of the rhizosphere in $-\mathrm{W}$. Another major contributor to cation-anion balance is $\mathrm{N}$, rhizosphere acidification being often indicative of a significant contribution of ammonium uptake. However, the data collected in this experiment showed that the $\mathrm{N}$ content in the aboveground biomass was lower in the throughfall exclusion treatment than in the control treatment (unpublished data). Nevertheless, $\mathrm{N}$ being possibly taken up as both nitrate and ammonium, it is impossible to know the relative contribution of ammonium uptake and whether this was affected by the throughfall exclusion treatment. The release of organic anions by roots can also contribute to the acidification of the rhizosphere, whenever it is accompanied by proton release (Hinsinger et al. 2003). In our experiment, the exudation of complexing compounds such as malate or citrate was 
probably of major importance for the roots to cope with the toxicity of aluminum, as induced by the ambient low $\mathrm{pH}$ of this soil, as shown in many plant species including eucalypt such E. grandis (Silva et al. 2004). However, we do not have direct evidence to support this assumption, and the related hypothesis that carboxylate exudation would be higher under rainfall exclusion.

\section{Accumulation of $\mathrm{K}$ in the rhizosphere}

Two hypothetical processes can be put forward to explain the observed increase in available $\mathrm{K}$ concentration in the rhizosphere relative to that in the bulk soil: the mass flow transport of K-ions across the rhizosphere leading to an accumulation at the vicinity of the roots (hypothesis 1) and the weathering of K-bearing minerals in the rhizosphere (hypothesis 2).

The experimental site of Itatinga has been heavily instrumented to study the biogeochemical cycles of nutrients. We can thus discuss hypothesis 1 by evaluating (i) the average quantity of $\mathrm{K}$ brought to the roots by mass flow and (ii) the amount of $\mathrm{K}$ taken up by the trees. Should the quantity of $\mathrm{K}$ brought by the mass flow be much lower than the amount of $\mathrm{K}$ actually taken up by the tree (as usually assumed, e.g. Barber 1995), then the mass flow hypothesis would be invalidated, as it could not explain the observed build-up of available $\mathrm{K}$ concentration within the rhizosphere.

We estimated these two amounts of $\mathrm{K}$ and for the 5th year of the former rotation cycle for which we had a complete dataset for E. grandis trees at the same location. Silvicultural practices and biomass production in this former rotation were similar to the $+\mathrm{W}$ treatment in the present experiment. The average quantity of $\mathrm{K}$ brought to the trees by mass flow, can be estimated by multiplying the volume of water taken up by the trees by the mean concentration of $\mathrm{K}$ in the soil solution. The average of annual rainfall can be a conservative estimate of the flux of water taken up by trees, as there is no loss of water by drainage after canopy closure (at age 2 years) in highly productive E. grandis plantations at the site (Laclau et al. 2013; Christina et al. 2016). We slightly overestimated the actual transpiration flux as we ignored the soil evaporation in our calculation. We used here the value measured for the 5 th year of the former rotation, which amounted to $13,510 \mathrm{~m}^{3} \mathrm{ha}^{-1}$ year ${ }^{-1}$. The mean value of $\mathrm{K}$ concentration over the same period down to the depth of $3 \mathrm{~m}$ was $0.16 \mathrm{mg} \mathrm{dm}^{-3}$ (Maquère 2008). The quantity of $\mathrm{K}$ brought by mass flow to trees was thus amounting to a maximum value of about $2 \mathrm{~kg} \mathrm{~K} \mathrm{ha}^{-1}$ year $^{-1}$. The amount of $\mathrm{K}$ taken up by the trees over the same period (the 5th year of the previous rotation), evaluated using the methodology described in Laclau et al. (2010), amounted approximately to $17.5 \mathrm{~kg} \mathrm{~K} \mathrm{ha}^{-1}$. This value is about an order of magnitude greater than the estimated annual flux of $\mathrm{K}$ delivered to trees by mass flow. These rough calculations clearly show that mass flow cannot explain the observed increase in K concentration in the rhizosphere of E. grandis trees, which is in line with what is usually expected for poorly mobile nutrients such as K (Barber 1995; Hinsinger et al. 2011a). Such calculations were not conducted for the throughfall exclusion treatment, for which all the data are not available yet, but the conclusion should be the same, given the huge discrepancy between mass flow and $\mathrm{K}$ uptake flux. We note that the data available for the 5 th year of the actual plantation concerning the accumulation of $\mathrm{K}$ in trees are consistent with the data used for the calculation that concerned the previous rotation cycle, for which all data were available.

The weathering of K-bearing minerals in soils can be a significant source of $\mathrm{K}$ for plant nutrition, and numerous studies have evidenced across spatial scales, from the rhizosphere to the catchment scale, that the uptake of $\mathrm{K}$ by plants can be a major driving force for the release of poorly-available soil $\mathrm{K}$ through enhanced weathering of K silicates (Taylor and Velbel 1991; Jaillard and Hinsinger 1993; Hinsinger et al. 1993; Velbel and Price 2007; Barré et al. 2007). While Hinsinger et al. (1993) demonstrated that $\mathrm{K}$ depletion in the rhizosphere was the primary process controlling the release of interlayer $\mathrm{K}$ from micas, a number of field studies in temperate and boreal forest ecosystems have rather reported an increase in $\mathrm{K}$ concentration in the rhizosphere than a depletion (e.g. Clegg and Gobran 1997; Turpault et al. 2005; Calvaruso et al. 2014). These authors interpreted such phenomenon as a consequence of the root-induced weathering of K-bearing minerals, occurring possibly through other processes than a shift of $\mathrm{K}$ exchange equilibria due to $\mathrm{K}$ uptake, e.g. rhizosphere acidification as demonstrated by Hinsinger et al. (1993), or the release of metal-complexing exudates.

The soil of the present study is highly weathered so that there are few amounts of easily-weatherable Kbearing minerals, especially 2:1 clay minerals able to retain interlayer $\mathrm{K}$. However, even in tropical soils, small amounts of 2:1 layers can be found in 1:1 clay minerals, which can dramatically influence the fate of 
soil K (Fontaine et al. 1989; Darunsontaya et al. 2012). Melo et al. (2007) demonstrated the occurrence of significant amounts of dioctahedral micas in the clay (kaolinite-dominated) fraction of Brazilian Ferralsol soils, including one developed on a similar parent material. Moreover, the weathering of primary minerals such as K-feldspars or muscovite, although least weatherable, is also a potential source of $\mathrm{K}$. It is known that the acidity increases the weathering rate of silicates (West et al. 2005), and the negative relationship between $\mathrm{K}$ concentration and $\mathrm{pH}$ found in the bulk soil (Fig. 6a) of the present experiment is consistent with the occurrence of such proton-promoted dissolution of K-bearing minerals in the studied soil. In addition, rhizosphere acidification has already been shown to be responsible for the release of cations from primary phyllosilicates by Hinsinger et al. (1993) in controlled conditions. The acidification-induced weathering process can thus be part of the explanation for the difference in $\mathrm{K}$ concentration found in the rhizosphere of the two treatments, as greater increase in $\mathrm{K}$ concentration concurred with greater acidification of the rhizosphere at depth in the throughfall exclusion treatment (-W, Fig. 4). The poor relationship between $\mathrm{pH}$ and $\mathrm{K}$ concentration that we found in the rhizosphere (Fig. 6b) is however suggesting that other processes than rhizosphere acidification contributed to increasing $\mathrm{K}$ concentration in soil solution through possibly enhanced weathering of K-bearing silicates.

To validate hypothesis 2 , the weathering rate should be greater than the actual $\mathrm{K}$ uptake rate achieved by roots, thus resulting in increased concentration of available $\mathrm{K}$ in the rhizosphere, as observed here in the two treatments and especially at depth for the throughfall exclusion treatment (-W, Fig. 4), and in a number of previous field studies on topsoil roots in temperate and boreal forest ecosystems (e.g. Clegg and Gobran 1997; Courchesne and Gobran 1997; Turpault et al. 2005, 2007; Calvaruso et al. 2014). It is not possible to estimate the weathering rate in our study, and such field data are scarce in the literature. Weathering rates have been estimated by Benedetti et al. (1994) in two watersheds of the same region of Brazil, but for basalt substratum instead of cretaceous sandstone. They estimated for labradorite, a K-feldspar present in their watersheds, that the rate of weathering was about $3 \mathrm{~kg} \mathrm{~K} \mathrm{ha}^{-1}$ year ${ }^{-1}$. Such estimates are not available for the cretaceous sandstone substrate present at the studied site and extrapolations shall be cautious as the impact of the vegetation in intensive eucalypt plantation is expected to be different from the sites studied by Benedetti et al. (1994), their watershed being composed of pasture, relict secondary forest and some crops. Given that, as Taylor and Velbel (1991) in their forest watersheds in the USA, Benedetti et al. (1994) stressed that there is a considerable impact of the vegetation on the estimated weathering rate for $\mathrm{K}$ bearing silicates, the actual weathering rate of our study site may be slightly bigger than $3 \mathrm{~kg} \mathrm{~K} \mathrm{ha}^{-1}$ year $^{-1}$, especially when considering that the $\mathrm{pH}$ of the soils developed on sandstone bedrock in our ecosystem was definitely more acidic than in the basalt watersheds studied by Benedetti et al. (1994). It is however unlikely to be much more than the annual demand of the E. grandis trees $\left(17.5 \mathrm{~kg} \mathrm{~K} \mathrm{ha}^{-1}\right)$. As an alternative to local weathering rate estimates, it is worth estimating the size of the stock of $\mathrm{K}$ contained in K-bearing silicates that can be potentially weathered. We estimated this stock based on the pseudo-total $\mathrm{K}$ analyses that we have conducted in the bulk soil along the soil profiles (Table 1). Based on these fairly low values, as commonly found in highly weathered tropical soils (Melo et al. 2005 and 2007), we estimated that this pool amounted to about $4700 \mathrm{~kg} \mathrm{~K} \mathrm{ha}^{-1}$, down to a depth of $4 \mathrm{~m}$. When taking into account the distribution of roots and the corresponding rhizosphere volume, assuming a radius of $1 \mathrm{~cm}$ (in such sandy soils, K-ion diffusion may probably occur over greater distances), pseudo-total $\mathrm{K}$ may amount to $204-221 \mathrm{~kg} \mathrm{~K} \mathrm{ha}^{-1}$, down to a depth of $4 \mathrm{~m}$. Melo et al. (2005) assessed the capacity of soils developed on the same parent material to supply nonexchangeable and structural $\mathrm{K}$ from $\mathrm{K}$-bearing silicates through weathering. They concluded that there was a substantial $\mathrm{K}$ release potential from the clay fraction of such soils, amounting to much more than the size of the exchangeable pool, amounting to about $3 \%$ of total $\mathrm{K}$, based on laboratory dissolution with $0.1 \mathrm{M}$ citric acid over about 2 months. One has to be careful when extrapolating to weathering rates under field conditions, but these findings substantiate the feasibility of a release of nonexchangeable or structural K in the order of $6 \mathrm{~kg} \mathrm{~K} \mathrm{ha}^{-1}$ (while the stock of exchangeable $\mathrm{K}$ in the rhizosphere is amounting to $1.4-$ $2 \mathrm{~kg} \mathrm{~K} \mathrm{ha}{ }^{-1}$, down to a depth of $4 \mathrm{~m}$ ) to explain the increase of exchangeable $\mathrm{K}$ concentration observed in the rhizosphere, amounting to $0.8-1.3 \mathrm{~kg} \mathrm{~K} \mathrm{ha}^{-1}$, down to a depth of $4 \mathrm{~m}$. Thus, hypothesis 2 cannot be rejected, although estimating the actual weathering rate would be needed to fully validate it. Our calculations are based on 
stocks at a given sampling time and cannot relate directly to the annual flux of $\mathrm{K}$ released by weathering.

This study is limited to a depth of $4 \mathrm{~m}$. However, in the experiment, the deepest roots reached a depth of $17 \mathrm{~m}$ depth in both $+\mathrm{W}$ and $-\mathrm{W}$ treatments. This characteristic is not linked to the studied clone, as such deep rooting depth has been shown also for other clones as well as for seedlings (Pinheiro et al. 2016). These roots have thus a potential access to an important stock of nutrients (very low concentration but on $>10-\mathrm{m}$ deep soil layer). Our results show that the rhizosphere effect seems to be higher at depth. Thus deep and very deep roots are likely to play a major role in tree nutrition in highly weathered tropical soils, and need to be accounted for and further studied.

To conclude, $\mathrm{pH}$ and nutrient concentrations in rhizosphere vs. bulk soil seem to be good indicators to evaluate the adaptive changes induced by climate change, notably water regime modification, on root functioning, including deep root functioning. Our study suggests an important role of the rhizosphere acidification process and consequent root-induced silicate weathering to explain the observed increase in $\mathrm{K}$ availability in the rhizosphere of E. grandis, although we did not provide direct evidence of such proton-promoted dissolution of K-bearing minerals. Interestingly, we pointed out that reduced rainfall resulted in larger rhizosphere effects, based on the fate of available $\mathrm{K}$ at depth compared with the topsoil. Potassium being a limiting nutrient in many tropical ecosystems, this study shows that accounting for deep soil layers and deep roots is crucially needed to better understand $\mathrm{K}$ nutrition of trees such as the deep-rooted eucalypt species (E. grandis) studied in this work.

Acknowledgements We acknowledge the staff at the Itatinga Experimental Station (ESALQ-USP) as well as Eder Araujo da Silva and Floragro (www.floragroapoio.com.br) for their technical support. This project was funded by the University of São Paulo, the Centre de coopération Internationale en Recherche Agronomique pour le Développement (CIRAD), the Agence Nationale de la Recherche (MACACC project ANR-13-AGRO0005, Viabilité et Adaptation des Ecosystèmes Productifs, Territoires et Ressources face aux Changements Globaux AGROBIOSPHERE 2013 program), USP-COFECUB (Project 2011-25), FAPESP (grant number 2013/25998-4) and AGREENIUM (Plantrotem project). This site belongs to the SOERE F-ORE-T, which is supported annually by Ecofor, Allenvi and the French national research infrastructure ANAEE-F (http://www.anaee-france.fr/fr/).

\section{References}

Aroca R (2012) Plant responses to drought stress: from morphological to molecular features. Springer Science \& Business Media

Barber SA (1995) Soil nutrient bioavailability: a mechanistic approach, 2 edn. Wiley

Barré P, Montagnier C, Chenu C et al (2007) Clay minerals as a soil potassium reservoir: observation and quantification through X-ray diffraction. Plant Soil 302:213-220. doi:10.1007/s11104-007-9471-6

Battie-Laclau P, Laclau JP, Domec JC et al (2014) Effects of potassium and sodium supply on drought-adaptive mechanisms in Eucalyptus grandis plantations. New Phytol 203: 401-413. doi:10.1111/nph. 12810

Battie-Laclau P, Delgado-Rojas JS, Christina M et al (2016) Potassium fertilization increases water-use efficiency for stem biomass production without affecting intrinsic wateruse efficiency in Eucalyptus grandis plantations. For Ecol Manag 364:77-89. doi:10.1016/j.foreco.2016.01.004

Benedetti MF, Menard O, Noack Y et al (1994) Water-rock interactions in tropical catchments: field rates of weathering and biomass impact. Chem Geol 118:203-220

Blossfeld S (2013) Light for the dark side of plant life: Planar optodes visualizing rhizosphere processes. Plant Soil 369: 29-32

Bravin MN, Martí AL, Clairotte M, Hinsinger P (2008) Rhizosphere alkalisation - a major driver of copper bioavailability over a broad $\mathrm{pH}$ range in an acidic, coppercontaminated soil. Plant Soil 318:257-268. doi:10.1007 /s11104-008-9835-6

Callesen I, Harrison R, Stupak I et al (2016) Carbon storage and nutrient mobilization from soil minerals by deep roots and rhizospheres. For Ecol Manag 359:322-331. doi:10.1016/j. foreco.2015.08.019

Calvaruso C, N'Dira V, Turpault MP (2011) Impact of common European tree species and Douglas-fir (Pseudotsuga menziesii [Mirb.] Franco) on the physicochemical properties of the rhizosphere. Plant Soil 342:469-480. doi:10.1007 /s11104-010-0710-x

Calvaruso C, Collignon C, Kies A, Turpault MP (2014) Seasonal evolution of the rhizosphere effect on major and trace elements in soil solutions of Norway Spruce (Picea abies Karst) and beech (Fagus sylvatica) in an acidic forest soil. Open J Soil Sci 4:323-336. doi:10.4236/ojss.2014.49034

Christina M, Laclau JP, Goncalves JLM et al (2011) Almost symmetrical vertical growth rates above and below ground in one of the world's most productive forests. Ecosphere 2: 2710

Christina M, Le Maire G, Battie-Laclau P et al (2015) Measured and modeled interactive effects of potassium deficiency and water deficit on gross primary productivity and light-use efficiency in Eucalyptus grandis plantations. Glob Chang Biol 21:2022-2039. doi:10.1111/gcb.12817

Christina M, Nouvellon Y, Laclau JP, Stape JL, Bouillet JP, Lambais GR, le Maire G (2016). Importance of deep water uptake in tropical eucalypt forest. Funct Ecol, in press

Christoffersen BO, Restrepo-Coupe N, Arain MA et al (2014) Mechanisms of water supply and vegetation demand govern 
the seasonality and magnitude of evapotranspiration in Amazonia and Cerrado. Agric For Meteorol 191:33-50

Clegg S, Gobran GR (1997) Rhizospheric P and K in forest soil manipulated with ammonium sulfate and water. Can J Soil Sci 77:525-533

Cocco S, Agnelli A, Gobran GR, Corti G (2013) Changes induced by the roots of Erica arborea L. to create a suitable environment in a soil developed from alkaline and fine-textured marine sediments. Plant Soil 368:297-313. doi:10.1007 /s11104-012-1501-3

Collignon C, Calvaruso C, Turpault M-P (2011) Temporal dynamics of exchangeable $\mathrm{K}, \mathrm{Ca}$ and $\mathrm{Mg}$ in acidic bulk soil and rhizosphere under Norway spruce (Picea abies Karst.) and beech (Fagus sylvatica L.) stands. Plant Soil 349:355-366. doi:10.1007/s11104-011-0881-0

Courchesne F, Gobran GR (1997) Mineralogical variations of bulk and rhizosphere soils from a Norway spruce stand. Soil Sci Soc Am J 61:1245. doi:10.2136 /sssaj1997.03615995006100040034x

da Silva EV, Bouillet JP, de Moraes Gonçalves JL et al (2011) Functional specialization of eucalyptus fine roots: contrasting potential uptake rates for nitrogen, potassium and calcium tracers at varying soil depths. Funct Ecol 25:996-1006. doi:10.1111/j.1365-2435.2011.01867.x

Darunsontaya T, Suddhiprakarn A, Kheoruenromne I et al (2012) The forms and availability to plants of soil potassium as related to mineralogy for upland Oxisols and Ultisols from Thailand. Geoderma 170:11-24. doi:10.1016/j. geoderma.2011.10.002

Davidson EA, Janssens IA (2006) Temperature sensitivity of soil carbon decomposition and feedbacks to climate change. Nature 440:165-173. doi:10.1038/nature04514

Eissenstat DM, Wells CE, Yanai RD, Whitbeck JL (2000) Building roots in a changing environment: implications for root longevity. New Phytol 147:33-42

EMBRAPA (1999) Sistema brasileiro de classificação de solos. Embrapa Solos, Centro Nacional de Pesquisa de Solos, Rio de Janeiro

Epron D, Cabral OMR, Laclau JP et al (2016) In situ (CO2)-C-13 pulse labelling of field-grown eucalypt trees revealed the effects of potassium nutrition and throughfall exclusion on phloem transport of photosynthetic carbon. Tree Physiol 36: 6-21. doi:10.1093/treephys/tpv090

FAO (1998) World reference base for soil resources FAO. ISRIC and ISSS, Rome

Fontaine S, Delvaux B, Dufey JE, Herbillon AJ (1989) Potassium exchange behaviour in Carribean volcanic ash soils under banana cultivation. Plant Soil 120:283-290

Göransson H, Rosengren U (2006) Nutrient acquisition from different soil depths by pedunculate oak. Trees-Struct Funct 20:292-298

Göransson H, Fransson A-M, Jonsson-Belyazid U (2007) Do oaks have different strategies for uptake of $\mathrm{N}, \mathrm{K}$ and $\mathrm{P}$ depending on soil depth? Plant Soil 297:119-125. doi:10.1007/s11104007-9325-2

Göransson H, Ingerslev M, Wallander H (2008) The vertical distribution of $\mathrm{N}$ and $\mathrm{K}$ uptake in relation to root distribution and root uptake capacity in mature Quercus robur, Fagus sylvatica and Picea abies stands. Plant Soil 306:129-137. doi:10.1007/s11104-007-9524-X
Hinsinger P, Elsass F, Jaillard B, Robert M (1993) Root-induced irreversible transformation of a trioctahedral mica in the rhizosphere of rape. J Soil Sci 44:535-545. doi:10.1111 /j.1365-2389.1993.tb00475.x

Hinsinger P, Plassard C, Tang C, Jaillard B (2003) Origins of rootmediated $\mathrm{pH}$ changes in the rhizosphere and their responses to environmental constraints: a review. (Special issue: Structure and functioning of cluster roots and plant responses to phosphate deficiency). Plant Soil 248:43-59

Hinsinger P, Gobran GR, Gregory PJ, Wenzel WW (2005) Rhizosphere geometry and heterogeneity arising from rootmediated physical and chemical processes. New Phytol 168: 293-303. doi:10.1111/j.1469-8137.2005.01512.x

Hinsinger P, Bengough AG, Vetterlein D, Young IM (2009) Rhizosphere: biophysics, biogeochemistry and ecological relevance. (Special Issue: Rhizosphere: achievements and challenges.). Plant Soil 321:117-152

Hinsinger P, Betencourt E, Bernard L et al (2011a) P for Two, sharing a scarce resource: soil phosphorus acquisition in the rhizosphere of intercropped species. Plant Physiol 156:10781086. doi:10.1104/pp.111.175331

Hinsinger P, Brauman A, Devau N et al (2011b) Acquisition of phosphorus and other poorly mobile nutrients by roots. Where do plant nutrition models fail? Plant Soil 348:29-61. doi:10.1007/s11104-011-0903-y

Huang B, Duncan RR, Carrow RN (1997) Drought-resistance mechanisms of seven warm-season turfgrasses under surface soil drying: II. Root aspects. Crop Sci 37:1863-1869

IPCC (2013) Climate change 2013: the physical science basis. Contribution of Working Group I to the fifth assessment report of the Intergovernmental Panel on Climate Change. In: Stocker TF, Qin D, Plattner G-K, Tignor MMB, Allen SK, Boschung J, Nauels A, Xia Y, Bex V, Midgley PM. eds. Cambridge, UK \& New York, NY, USA: Cambridge University Press

Jaillard B, Hinsinger P (1993) Root-induced release of interlayer potassium and vermiculitization of phlogopite as related to potassium depletion in the rhizosphere of ryegrass. J Soil Sci 44:525-534

Kell DB (2011) Breeding crop plants with deep roots: their role in sustainable carbon, nutrient and water sequestration. Ann Bot 108:407-418. doi:10.1093/aob/mcr175

Laclau JP, Almeida JCR, Gonçalves JLM et al (2009) Influence of nitrogen and potassium fertilization on leaf lifespan and allocation of above-ground growth in Eucalyptus plantations. Tree Physiol 29:111-124. doi:10.1093/treephys/tpn010

Laclau JP, Ranger J, de Moraes Gonçalves JL et al (2010) Biogeochemical cycles of nutrients in tropical Eucalyptus plantations. For Ecol Manag 259:1771-1785. doi:10.1016/j. foreco.2009.06.010

Laclau JP, da Silva EA, Rodrigues Lambais G et al (2013) Dynamics of soil exploration by fine roots down to a depth of $10 \mathrm{~m}$ throughout the entire rotation in Eucalyptus grandis plantations. Front Plant Sci. doi:10.3389/fpls.2013.00243

Maeght JL, Rewald B, Pierret A (2013) How to study deep rootsand why it matters. Front Plant Sci. doi:10.3389 /fpls.2013.00299

Maquère V (2008) Dynamics of mineral elements under a fastgrowing eucalyptus plantation in Brazil. Implications for soil sustainability, Ph.D thesis Agro Paris Tech and USP-ESALQ, Brazil 
Maurice J, Laclau JP, Re DS et al (2010) Fine root isotropy in Eucalyptus grandis plantations. Towards the prediction of root length densities from root counts on trench walls. Plant Soil 334:261-275

Melo VF, Corrêa GF, Ribeiro AN et al (2005) Cinética de liberação de potássio e magnésio pelos minerais da fração argila de solos do Triângulo Mineiro. Rev Brasil Ciênc Solo 29:533-545. doi:10.1590/S0100-06832005000400006

Melo VF, Schaefer CEGR, Novais RF et al (2007) Potassium and magnesium in clay minerals of some Brazilian soils as indicated by a sequential extraction procedure. Commun Soil Sci Plant Anal 33:2203-2225. doi:10.1081/CSS-120005757

Nadezhdina N, David TS, David JS et al (2010) Trees never rest: the multiple facets of hydraulic redistribution. Ecohydrology 3:431-444. doi:10.1002/eco.148

Peel MC, Finlayson BL, McMahon TA (2007) Updated world map of the Köppen-Geiger climate classification. Hydrol Earth Syst Sci 11:1633-1644. doi:10.5194/hess-111633-2007

Philippot L, Raaijmakers JM, Lemanceau P, van der Putten WH (2013) Going back to the roots: the microbial ecology of the rhizosphere. Nat Rev Microbiol 11:789-799. doi:10.1038 /nrmicro3109

Pinheiro RC, de Deus JC, Nouvellon Y et al (2016) A fast exploration of very deep soil layers by Eucalyptus seedlings and clones in Brazil. For Ecol Manag 366:143-152. doi:10.1016 j.foreco.2016.02.012

Reinhold-Hurek B, Bünger W, Burbano CS et al (2015) Roots shaping their microbiome: global hotspots for microbial activity. Annu Rev Phytopathol 53:403-424. doi:10.1146 /annurev-phyto-082712-102342

Rewald B, Godbold DL, Falik O, Rachmilevitch S (2014) Root and rhizosphere processes - high time to dig deeper. Front Plant Sci 5:278

Römheld V, Kirkby EA (2010) Research on potassium in agriculture: needs and prospects. Plant Soil 335:155-180. doi:10.1007/s11104-010-0520-1

Santiago LS, Wright SJ, Harms KE et al (2012) Tropical tree seedling growth responses to nitrogen, phosphorus and potassium addition. J Ecol 100:309-316. doi:10.1111/j.13652745.2011.01904.x
Schenk HJ, Jackson RB (2002) Rooting depths, lateral root spreads and below-ground/above-ground allometries of plants in water-limited ecosystems. J Ecol 90:480-494

Silva IR, Novais RF, Jham GN et al (2004) Responses of eucalypt species to aluminum: the possible involvement of low molecular weight organic acids in the Al tolerance mechanism. Tree Physiol 24:1267-1277

Sokolova TA (2015) Specificity of soil properties in the rhizosphere: analysis of literature data. Eurasian Soil Sci 48:968980. doi:10.1134/S1064229315050099

Taylor AB, Velbel MA (1991) Geochemical mass balances and weathering rates in forested watersheds of the southern blue ridge II. Effects of botanical uptake terms. Geoderma 51:29-50

Thom D, Seidl R (2015) Natural disturbance impacts on ecosystem services and biodiversity in temperate and boreal forests. Biol Rev Camb Philos Soc. doi:10.1111/brv.12193

Turpault MP, Uterano C, Boudot JP, Ranger J (2005) Influence of mature Douglas fir roots on the solid soil phase of the rhizosphere and its solution chemistry. Plant Soil 275:327-336

Turpault M-P, Gobran GR, Bonnaud P (2007) Temporal variations of rhizosphere and bulk soil chemistry in a Douglas fir stand. Geoderma 137:490-496. doi:10.1016/j. geoderma.2006.10.005

Van Raij B, Quaggio JA (2001) Determinação de fósforo, cálcio, magnésio e potássio extraídos com resina trocadora de íons. In: van Raij B, de Andrade JC, Cantarella H, Quaggio JA (eds) Análise química para avaliação da fertilidade de solos tropicais. Instituto Agronômico, Campinas, Brazil, pp 189-199

Velbel MA, Price JR (2007) Solute geochemical mass-balances and mineral weathering rates in small watersheds: Methodology, recent advances, and future directions. Appl Geochem 22:1682-1700. doi:10.1016/j . apgeochem.2007.03.029

West A, Galy A, Bickle M (2005) Tectonic and climatic controls on silicate weathering. Earth Planet Sci Lett 235:211-228. doi:10.1016/j.eps1.2005.03.020

Wu Z, Dijkstra P, Koch GW, Peñuelas J, Hungate BA (2011) Responses of terrestrial ecosystems to temperature and precipitation change: a meta-analysis of experimental manipulation. Glob Chang Biol 17:927-942 